\title{
The Effect of Aspirin on Gomori-positive Glia in Mouse Brain*
}

\author{
Piotr SURA, Zbigniew SREBRO, Bogdan WILIŃSKI and Marta GÓRALSKA
}

Accepted October 10, 2007

\begin{abstract}
SURA P., SREBRO Z., WILIŃSKI B., GÓRALSKA M. 2008. The effect of Aspirin on Gomori-positive glia in mouse brain. Folia biol. (Kraków) 56: 73-75.

Aspirin (acetylsalicylic acid, ASA) treatment resulted in a significant decrease in the amount of the sulfur-rich Gomori-positive material present in the cytoplasm of periventricular glia. It also caused the accumulation of the Gomori-positive neurosecretory material in the supraoptic and paraventricular nuclei and, most pronounced, in the neurosecretory axons of the paraventricular- and supraoptic-neurophypophysial tract.
\end{abstract}

Key words: Gomori-prositive glia, aspirin, mouse.

Piotr SURA, Zbigniew SREBRO, Bogdan WILIŃSKI, Marta GÓRALSKA, Departament of Human Developmental Biology, Collegium Medicum, Jagiellonian University, Kopernika 7, 31-034 Kraków, Poland.

E-mail:mbsura@cyf-kr.edu.pl

The Gomori-positive glia are a type of predominantly periventricularly localized astrocytes having abundant cytoplasmic material that can be stained using Gomori's chrome hematoxylin. The number of such cells as well as the amount of the glial Gomori-positive material (GGMP) vary with the strain of animals, their age, and sex. Gomoripositive glial cells are present in all mammalian species so far examined, and their number varies in some experimental conditions (SREBRO 1971; SREBRO \& LACH 1972; SREBRO et al. 2006). The GGMP is strongly reducing and contains a considerable amounts of sulfur (SREBRO \& MACIŃSKA 1972). Recently, we (SREBRO et al. ms submitted) have shown that the sulfur in the GGMP is sulfane sulfur, i.e. atoms of sulfur bound only to other sulfur atoms and so having an oxidation state 0 or -1 (TOOHEY 1989). This sulfane sulfur can be a source of the sulfur found in iron-sulfur clusters and it may also serve as a detoxificant for xenobiotics and as a scavenger of reactive oxygen species (WŁODEK 2003).

A recent finding (SREBRO et al. 2006) shows that ASA elevates the level of hydrogen sulfide in mouse brain. Therefore, since the GGMP is abundant in sulfur, the action of ASA on GGMP seems warranted.

\section{Material and Methods}

Young adult 3 to 6 month-old BALB/c male and female mice were used. The animals were housed under standard laboratory conditions, fed a stan- dard laboratory chow, and had free access to water. They were kept in an environmentally controlled room at $22-24^{\circ} \mathrm{C}$ with a light/dark cycle of $12 \mathrm{~h}$. Four animals were injected intraperitoneally (i.p.) with 6 or $10 \mathrm{mg}$ of ASA dissolved in $0.2 \mathrm{ml}$ physiological saline for 5 days. Four control animals received i.p. $0.2 \mathrm{ml}$ saline. The experimental and control mice were sacrificed on the $5^{\text {th }}$ day of the experiment, $3 \mathrm{~h}$ after the last injection.

Immediately after the death of the animals their brains were exposed by removal of the skin and cranial vault and were fixed in situ with Bouin's fluid for $24 \mathrm{~h}$. Subsequently, the brains were dehydrated in graded concentrations of ethanol, cleared in xylene and embedded in paraffin. Seven $\mu \mathrm{m}$ sections were stained with Gomori's chrome hematoxylin-phloxin method (PEARSE 1960). The amount of sulfur-rich glial Gomori-positive material present in a visual field under x400 magnification in 20 adjacent sections was evaluated, as well as the amount of Gomori-positive neurosecretion present in perikarya and axons of neurosecretory supraoptic and paraventricular nuclei and the neural lobe.

\section{Results}

Evaluation of the histological sections revealed that ASA-treatment resulted in a highly significant decrease of the sulfur-rich Gomori-positive mate- 
rial in the periventricular glia (Figs $1 \& 2$ ). At the same time there was a significant increase in the amount of Gomori-positive neurosecretory substance, particularly in the axons of the supraopticand paraventricular-neurohypophysial tract (Figs $3 \& 4)$. Since enlargement of the nuclei in the neu-
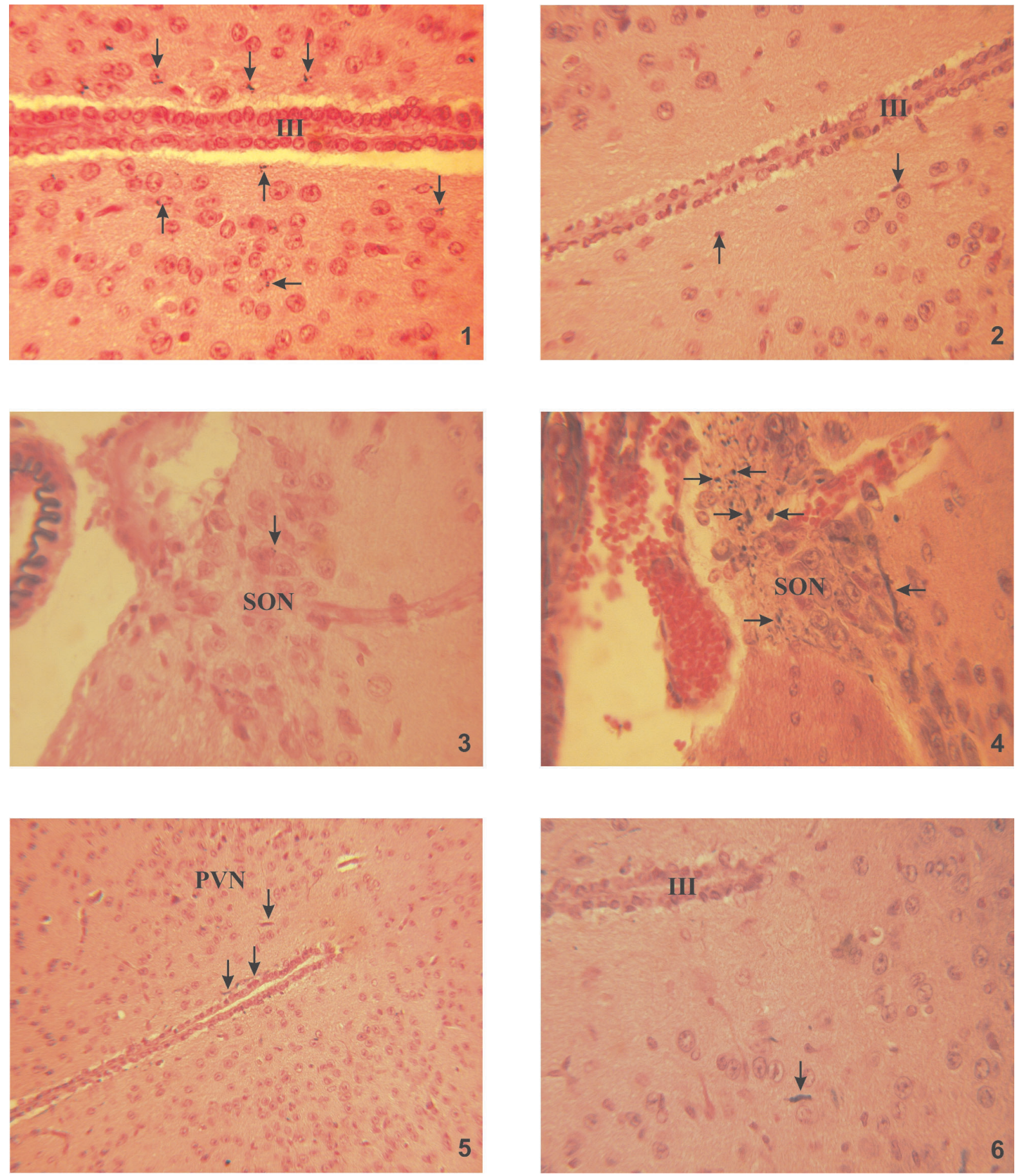

Figs 1-6. Fig. 1. Numerous Gomori-positive astrocytes (arrows) near the third brain ventricle (III) in a control female. Chrome hematoxylin-phloxin (CHP), $\times$ 400. Fig. 2. Third brain ventricle (III) and surrounding neuropile in $6 \mathrm{mg}$ ASA-treated female. No Gomori-positive astrocytes are present. Arrows show pyknotic nuclei of periventricular glia. CHP, $\times 400$. Fig. 3 . Supraoptic nucleus (SON) in a control female. Note the cell nuclei but no Gomori-positive neurosecretion. Arrow shows a Gomori-positive astrocyte. CHP $\times$ 400. Fig. 4. Supraoptic nucleus $(\mathrm{SON})$ in $10 \mathrm{mg}$ ASA-treated female. Note the abundant masses of the Gomori positive neurosecretion (arrows). CHP, $\times 400$. Fig. 5. Paraventricular nucleus (PVN) of $6 \mathrm{mg}$ ASA-treated female. Arrows show Gomori-positive neurosecretion in axons of the paraventriculo-neurohypophysial tract. CHP, $\times 200$. Fig. 6. Neurosecretory axon of the paraventriculo-neurohypophysial tract (arrow) of 6 mg ASA-treated female at higher magnification. The visible fragment of the axon is dilated with a mass of Gomori-positive neurosecretory substance. The third brain ventricle (III), $\times 400$. 


\section{Discussion}

The significant decrease of the sulfur-rich Gomori-positive material in the periventricular glia can be interpreted as mobilization of the glial sulfur stores for production of endogenous $\mathrm{H}_{2} \mathrm{~S}$. On the other hand, a diminished supply of sulfur compounds may also be the cause. It is well known that neurophysin, a carrier for vasopressin and oxytocin, is present in the cerebrospinal fluid (BROWNFIELD \& KOZLOWSKI 1977; AMICO et al. 1990; NORTH et al. 1992) and reduced secretion of vasopressin-neurophysin and oxytocin-neurophysin can be inferred from the reduced activity of the Gomori-positive neurosecretory system. Neurophysin contains 7 cysteine residues (DRENTH 1981) and is therefore a rich source of sulfur taken up and stored in the paraventricular glia. Recent results show that the glial Gomori-positive material is sulfane sulfur (ms submitted) and as such can be used as a sulfur donor for other sulfurcontaining molecules like $\mathrm{H}_{2} \mathrm{~S}$. On the other hand, it has been shown that ASA increases the concentration of $\mathrm{H}_{2} \mathrm{~S}$ in the brain (SREBRO et al. 2006). It is most probable that the sulfur in the GGPM is derived from sulfur-rich material such as neurophysin and/or vasopressin and oxytocin. Sulfane sulfur in the Gomori-positive glia probably has other important physiological functions and may serve as a trap for xenobiotics and reactive oxygen species present in the interstitial fluid of the brain parenchyma and in the cerebrospinal fluid. The accumulation of the neurosecretory substance after ASA treatment can be interpreted as stasis of the Gomori-positive neurosecretion and decreased release into the blood and the cerebrospinal fluid, since no enlarged cell nuclei have been observed in the neurosecretory neurons of the supraoptic and paraventricular nuclei. Moreover, DELLO RUSSO et al. (2000) have reported that $\mathrm{H}_{2} \mathrm{~S}$ can modulate the hypothalamo-pituitary axis, inhibiting the stress-related hypothalamo-pituitary axis activity.

\section{References}

AMico J. A., JANOSKY J. E., CAMERON J. L. 1990. Effect of estradiol and progesterone administration upon the circadian rhythm of oxytocin in the cerebrospinal fluid of rhesus monkeys. Neuroendocrinology 51: 543-551.

BROWNFIELD M. S., KOZLOWSKI G. P. 1977. The hypothalamo-choroidal tract. I. Immunohistochemical demonstration of neurophysin pathways to telencephalic choroid plexuses and cerebrospinal fluid. Cell Tissue Res. 178: 111-127.

Dello Ruso C., TRingali G., Ragazzoni E., Maggiano N., MENINI E., VAIRANO M., PREZIOSI P., NAWARRA P. 2000. Evidence that hydrogen sulfide can modulate hypothalamo-pituitary-adrenal axis function. In vitro and in vivo studies in the rat. J. Nueroendocrinol. 12: 225-233.

DRENTH J. 1981. The structure of neurophysin. J. Biol. Chem. 256: 2601-2602.

North W. G., HARBAugh R., ReEder T. 1992. An evaluation of human neurophysin production in Alzheimer's disease: preliminary observations. Neurobiol. Aging 13: 261-265.

PEARSE A. G. E. 1960. Histochemistry, Theoretical and Applied. Churchill, London.

SREBRO Z. 1971. Periventricular Gomori-positive glia in brains of X-irradiated rats. Brain Res. 35: 463-468.

SREBRO Z., LACH H. 1972. X-ray- and UV-induced increase in number of cysteine-rich periventricular glial cells in the brains of rats and mice. Acta biol. Acad. Sci. hung. 23: 145-151.

SREBRO Z., MACIŃSKA A. 1972. In vitro growth of Gomoripositive glia. Brain Res. 32: 27-33.

SRebro Z., SOMOGYi E., WilińsKi B., GóralsKA M., WILIŃSKI J., SURA P. 2006. Aspirin augments the concentration of endogenous hydrogen sulfide in mouse brain and liver. Folia Med. Cracov. 47: 87-91.

SREBRo Z., SURA P., WILIŃSKI B. 2006. Gomori-positive glia and mast cells in the brains of various laboratory strains of mice under normal and experimental conditions. Acta Biol. Cracov. Ser. Zool. 48: 31-38.

TOOHEY J. L. 1989. Sulphane sulphur in biological systems: a possible regulatory role. Biochem. J. 264: 625-632.

WŁODEK L. 2003. Biothiols. The Jagiellonian University Press, Kraków. 